\title{
What is the Sustainability of Village Savings and Loans Associations (VSLAs) Amidst of Covid-19? Its Impact on Household Income Level and its Determining Factors-Lessons from Malawi, Sub-Saharan Africa
}

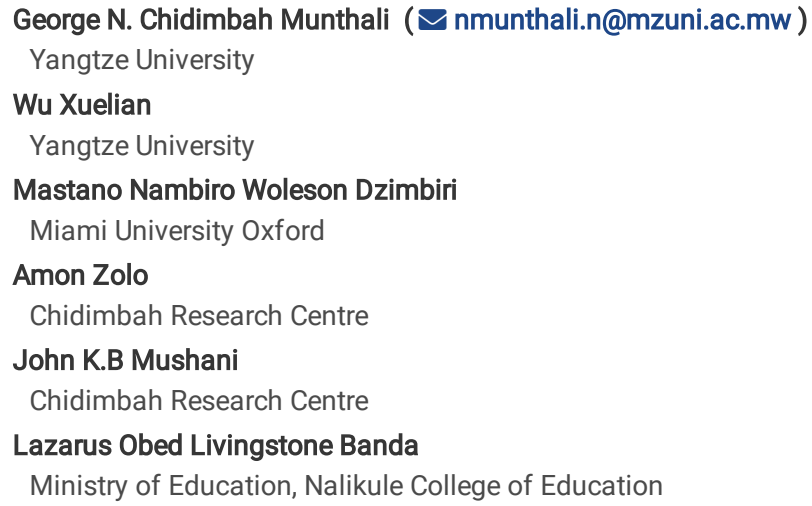




\section{Abstract}

Background: Food security, malnutrition and poverty are some of the challenges that most of the sub-Saharan African countries face, with the coming of Covid-19 the sustainability of Village Savings and Loans Association which are formed to counter fight these challenges is questioned.

Aim: The aim of this study was to assess factors associated with the Sustainability of VSLAs amidst of Covid-19 and its impacts on households' income levels.

Methods: An online cross-sectional design was conducted from November to January 2021, targeting VSLAs members in Mzuzu. A snowball and respondentdriven sampling technique was used to recruit the needful participants using a referral approach. IBM SPSS version 23 was used to perform descriptive statistics, Chi-Square, and binary logistic regression with unstandardized Beta ( $\beta$ ), Odds Ratios (OR), and 95\% Confidence Interval (Cl) being taken into account with P-value set at P-value at $0.1,0.05$ and 0.01 significance levels.

Results: Our study finds that household income declined by $54 \%$ for those earnings belonged to $₫$ MK5,000, as compared to $38 \%$ and $15 \%$ for medium (MK5,000 $\geq$ MK10,000) and higher (>MK10,000) income bands respectively. Our study shows that gender $(\beta=0.437, p=0.094)$, age-group $(\beta=1.317, p=0.000)$, education ( $\beta=2.181, p=0.047)$, share contributions $(\beta=1.035, p=0.008)$, and meetings $(\beta=0.572, p=0.021)$, and occupation $(\beta=-0.453, p=0.106)$, frequency of meeting $(\beta=-0.507, p=0.049)$ were positively and negatively statistically significant predictors.

Conclusion: Findings of this study shows that households with lower income earnings as one of the indicators of poverty are more affected by the pandemic than their counterparts. We recommend that the policymakers should continue and adopt, if they have not yet, programs that would help to assist low-income households, such as transfer of payments, which have proved to boost the income of the poor in many developing countries.

\section{Background}

Since the outbreak of Covid-19 in 2019 in the city of Wuhan in Hubei Province in the People's Republic of China, the virus is said to be caused by respiratory syndrome, and people with prevalent underlying health conditions are more prone to the infection [1, 2]. According to public health experts, the human to human viral transfer from has caused many deaths as well as considerably negative impact on the economic, social, and political activities globally [3-6]. Scholars have written on how Covid-19 impacts the global economies such that has been spared no single country from its fate.

Over the past decades, there has been a proliferation of groups of people with common economic targets and desires to generate and save money among themselves. More than two people with common interests come together to form a VSLAs group with the aim of saving, borrowing, and even making insurance funds in the form of shares that they buy at the beginning and act as the amount of contribution per defined period. Countries across the globe have different terms for these Village Savings and Loans Associations (VSLAs) differently, irrespective of the groups bearing the same goals [7]. For instance, in Egypt they are called Rotating Savings and Credit Associations (ROSCAs) or, Accumulated Savings and Credit Associations [8, 9]. Loans obtained from these associations are of low interest compared to other microfinance banks. Many of these VSLAs are not registered with the registrar of the business. They usually act on a trust basis since they just unite people from the same village, workplace, church, or any other common ground. Usually, the activity runs for a cycle of one year or so. After the end of the cycle, the members share the dividends themselves[10, 11].

VSLAs have for the past decades or so proven to be one of the remarkable tools, platforms, modes or drivers of economies worldwide positively impacting the living standards of the rural dwellers especially in the developing countries[12,13]. For instance, out of 176 of the significant and most sustainable MFIs found in seventeen Latin American countries, forty-seven of them are into village banking [14]. Besides, literature indicates that in African countries like Ghana, Malawi, Rwanda, Kenya, Sierra Leone, Egypt, Ethiopia, Uganda, Nigeria, where CARE international and VSL Associates implement their programmes, similar impacts of VSLAs on members' lives and the economy in general have manifested [12,15-17]. More importantly, the VSLs have significantly promoted gender equality by empowering women through economic decision-making at household and group levels $[9,12,18]$. Further, the program has helped to reduce or eradicate poverty by increasing the disposal income to individual members as well as increasing agricultural productivity through loans enabling them to afford farm inputs throughout the cycle $[15,19,20]$. Besides, the VSLs have helped reduce maternal health problems in developing countries as women can access instant loans to pay for convenient transportation to seek medical relevant attention [17].

While appreciating all the positive impacts of VSLAs, it is worthy to note that the spread of Covid-19 has also affected the operations of these VSLAs, which has further challenged its sustainability. Despite the voluminous literature about the impact of Covid-19 on people's lives, there is little systematic documentation as to how the pandemic has impacted the Village Savings and Loans Associations (VSLAs) performances among residents in developing countries like Malawi. Our study fills this gap by examining the socio-economic status and sustainability of VSLAs. We achieved our goal by answering the following research questions: (i) What are the impact of covid-19 on household income levels (ii) What factors determine the sustainability of VSLAs?

\section{Methods}

\section{The aim}

The aim of this study was to assess factors associated with the Sustainability of VSLAs amidst of Covid-19 and its impacts on households' income levels.

\section{Study design}

This study used a quantitative method design to extrapolate in-depth information about the topic under study [21, 22]. In this study we used an online crosssectional survey. The study was conducted in Malawi, Africa. Malawi is located in the southern part of Africa, bordering countries like Zambia, Tanzania, and 
Zimbabwe. It is one of the least developing countries in the world where a majority of its population still faces hunger, malnutrition's and live under the poverty line [23-25], and depend mostly on agriculture for business and feeding the population [26]. In Malawi, the study was conducted in Mzuzu city, which is located in the northern part with an estimated total population of 221, 272, and a land area of 143.8 square kilometres as of 2019 , that is divided into 14 wards, namely; Chibanja, Chibavi West, Chibavi East, Chiputula, Jombo-Kaning'ina, Katawa, Lupaso-Nkhorongo, Luwinga, Masasa, Mchengautuwa East, Mchengautuwa West, Mzilawaingwe, Zolozolo East, and Zolozolo West) as shown in Figure 1, with the majority of its populations depending on agriculture activities, business, and working as civil servants in many governmental and non-governmental intuition s that are found in the city, furthermore, According to recent studies, Mzuzu City has been attributed as one of the fastest growing city in Malawi, due to its social economic activities [27]. Therefore, upon looking at all these factors it was worthwhile to conduct this study in this city in order to investigate the Impacts on Covid-19 which could have a negative impact on the record of this city.

\section{Data Collection Procedures}

This study collected data from various VSLAs members operating within Mzuzu City. Data collection exercise was done between November 2020 and January 2021. We recruited and trained a team of four research assistants, who were guided on the aims and how to conduct the study. These research assistants helped to identify VSLAs groups and its members and facilitated the collection of the online survey headed by Mr. Zolo (as head of the Research assistants). The questionnaire was sent to the participants using Facebook, WhatsApp and email due to the Covid-19 gathering restrictions, as the study was conducted when there were some social distance measures being enforced in Malawi. The targeted respondents identified were forwarded the questionnaires links with assistance from the recruited research assistants.

\section{Inclusion and Exclusion Criteria}

All members of VSLAs that were operating within Mzuzu localities, who were below 18 years old were excluded in the survey. To ensure that the respondents were from that country and city, a space was provided in the questionnaire instrument where the respondent stated his country and city of residence. All those who indicated outside the study areas were to be excluded.

\section{Population, Sample Size, and Technique}

The study recruited the respondents that were members of VSLAs in the designated study area. A snowball and respondent-driven sampling technique was used to select the area and determine the sample population. We employed this technique based on the following reasons. First, it was easy to access data due to the researchers' connections with people associated with VSLAs in the selected country. Second, due to the impact of COVID-19, it is not easy to collect the data physically, taking into consideration the social distance measures in place in all countries [28-30].

We recruited 402 participants in the survey who met the inclusion and exclusion criteria. We employed a sampling calculation used by Yamane, with a $95 \%$ Confidence Level and, P=0.05 [31], N=Total Population of Mzuzu City =221,272 [27].

$x=\frac{N}{1+N(e)^{2}}$

Which gave us 399 , as the minimum required number of participants.

\section{Questionnaire' design}

The questionnaire had three sections.

\section{i. Demographic data}

The first sections captured the social demographic data of the VSLAs members which include; the respondent's gender, age-group, occupation, education level, status of the head and number of people in the house of which they were measured in the category and coded in binary form (Table 1).

\section{ii. Impact of Income on Covid-19}

The second part of the questionnaire captured data on the impact of Covid-19 on income of the participants. We asked the respondents to indicate the category of income that they earn per month prior and during the outbreak of Covid-19. The income was put in categories/groups of three income bands or levels. The first one was those falling under Less than MK5,000, then those under or above MK5,000 but less than MK10,000, and finally those above MK10,000 (Table 1).

\section{iii. Performance and sustainability Indicators}

The third part of the questionnaire captured the data on the performance which predicted its sustainability of the VSLAs in the midst of Covid-19 based on literature. Members were asked questions regarding the impacts of COVID-19 on; loan repayment in time, loan obtainment frequency, share contributions in time or not, and if the members were meeting. All variables were categorical in nature and were measured in binary form (Table 1).

\section{Validity and Reliability}

A pilot study was conducted to pre-test the instruments before the actual collection of data which involved 43 respondents comprising VSLAs members, Masters' and PhD students. The validity and reliability of the instrument was tested by sending the instrument to experts for comments before actual data 
collection. The research instrument was tested by using Cronbach's Alpha in SPSS and was found to be 0.8 .

\section{Ethical Clearance}

Ethical clearance of this study was obtained from Yangtze University with reference Number REF/YU/2020/08. Further, the researchers observed and followed the 1964 Helsinki Declaration under conducts of research involving human beings. In accessing Mzuzu city, the clearance was obtained from Mzuzu City Council authorities in Malawi with a reference Number MCC/ dated on July 20, 2020 from the Chief Executive Officer Office. Participation in the survey was voluntary and the participants gave their informed consent to this questionnaire before completion.

\section{Data Analysis}

After collecting the data using the google form, we coded in the Microsoft Excel and later imported it into SPSS Version 23 for analysis. We presented the results of the descriptive statistics using frequency tables, graphs, and charts. The Chi-Square test was performed to determine associations between sociodemographic variables and other variables. $P$ value was statistically significant at $p<0.05$. Lastly, due to the nature of our dependent variables, a binary logistic regression model was performed.

\section{Econometric Model Specification}

This was used to address our second research question: to predict the factors associated with the sustainability of VSLAs. We used Certainty of Future of VSLAs as our dependent variable, which was coded or characterized as a two-categorical variable. The coding was that if the VSLAs members attest that they have certainty in the future and sustainability of VSLAs regarding the current situation of Covid- 19 , then the value given was 1 ; otherwise, 0 . Therefore, the dichotomy of the dependent variables directed and suggested to us used the binary logistic regression model, which was deemed fit as used by other scholars[32-34].

In this study, a logistic regression model, the dichotomous variable is defined as,

$y=\int_{0}^{1}$ whereas $1=$ The Presence of the Characteristics 0

\section{$=$ The absence of the Characteristics}

Whereas the odd is defined as,

Odds $=\frac{p}{p-1}=\frac{\text { The Probability of the Presence of the characteiricts }}{\text { The probability of the absence of the characteristics }}$

Whereas the definition of the logit Model is like this,

$\left.\operatorname{Logit}(p)=\beta_{0}+\beta_{1} X_{1}+\beta_{2} X_{2}+\beta_{3} X_{3}+\ldots \ldots \ldots \ldots+\beta_{k} X_{k}+e \ldots \ldots \ldots \ldots . .33,35\right]$

Where the probability of the presence of the characteristic of interest is represented with $\mathrm{p}$. The logit transformation is defined as the log of odds.

$\log \left(\frac{p}{1-p}\right)=\operatorname{Logit}(\mathrm{p})=\beta_{0}+\beta_{1} \mathrm{X}_{1}+\beta_{2} \mathrm{X}_{2}+\beta_{3} \mathrm{X}_{3}+\ldots \ldots \ldots \ldots+\beta_{\mathrm{k}} \mathrm{X}_{\mathrm{k}}+\mathrm{e} \ldots \ldots \ldots \ldots . .[33,35]$

Whereas;

$\beta_{0}=$ Constant,

$\beta_{1}-\beta_{k}=$ are the coefficients of logistic regression,

$\mathrm{X}_{1}-\mathrm{X}_{\mathrm{k}}=$ are independent explanatory variables, and

$\mathrm{e}=$ is an error term.

\section{Results}

The results of this study reveal that a total number of 402 VSLAs members participated in responding to the survey representing a $100 \%$ plus after meeting a target of 399, which was found using the sampling techniques (Table 2).

\section{Socio-demographic characteristics and Future of VSLAs amid Covid-19.}

Table 2 shows that the majority of the respondents were male $(64 \%, n=259)$ and were statistically significant associated to the certainty of the future of the $\operatorname{VSLAs}(\chi 2$ Test $=4.462, \mathrm{p} \otimes 0.05)$. Most of these were above 30 years of age $(60 \%, n=244)$, which was also statistically significantly associated with the VSLAs ( $\chi 2$ Test=36.75, p囚0.05). Majority of these were not formally employed either in government or NGOs $71 \%(n=288)$, despite that they attained a certain level of 
education $96 \%(n=218)$ and was also statistically significantly associated with the certainty of VSLAs ( $\chi 2$ Test=13.105) p $\varangle 0.05)$. Further, the results show that the majority of the respondents were heads of households $(69 \%, \mathrm{n}=279)$ and was also found statistically significantly associated with the certainty of VSLAs $(\chi 2$ Test $=4.249, \mathrm{p} \otimes 0.05)$. Most of these had also households with more than 6 members on average $(\mathrm{n}=262)$.

\section{Impact of Covid-19 on income of the VSLAs Members}

Regarding change in household income, the results show that the majority of the respondents reported a downward shift in earning (lower) income per month of less than MK5,000 with an approximate of $54 \%(n=74)$ during the pandemic (Table 3 and Figure 2). This has caused a tremendous negative effect on the medium income band of above MK5,000.00 but less than MK10,000.000 with an approximately -38.62 ( $n=-56$ ) decline, and on the last income band, of above MK10,000.00 also indicated a decline with a lower percentage of $15 \%$ compared to the previous income band. Using the ANOVA test, results show statistically significant at $p$-value of .05 level of significance with $\mathrm{F}=103.705, p=0.000$ (Mean=2.19, $\mathrm{SD}=0.7$ ) values thus before and during $\mathrm{F}=101.78, p=0.000$ (Mean=1.96, SD=0.8).

\section{Predicting the Factors associated with the Future and sustainability of VSLAs amid Covid-19}

We performed a binary logistic regression to predict factors associated with the Future and sustainability (certainty) of the VSLAs (Table 4). Our findings revealed that the model fitted the data as the Hosmer and Lemeshow Test was found not-Significant at $P$-value $=0.389(>0.05)$. Further, in this model, we have tried to explain a variance of 19.2 to $26.2 \%$ based on Cox and Snell R2 and Nagelkerke R2 values, respectively. The Model further gave a $68.10 \%$ Model Predicted Success.

After assessing the explanatory variables inputted in the model, out of 10 variables, seven were statistically significantly and these includes gender $(\beta=0.437$, $p=0.094)$, age $(\beta=1.317, p=0.000)$, education $(\beta=2.181, p=0.047)$, shared contributions $(\beta=1.035, p=0.008)$, and meetings $(\beta=0.572, p=0.021)$. However, occupation ( $\beta=-0.453, p=0.106)$ and frequency of meetings $(\beta=-0.507, p=0.049)$ were not significant predictors. On the other hand, household head ( $\beta=-0.002$, $p=0.994)$, number of household members $(\beta=-0.174, p=0.481)$, and loan repayment $(\beta=-0.368, p=0.372)$ were also not significant predictors in the model.

Further, to increase the reliability by not only depending on the values of the coefficients, we assessed the odds ratios explained as a probability of the VSLAs members being certain about its future based on the literature (Kunst, 2013). Thus, our results revealed that males had 1.55 times (odds ratio [OR]: 1.548 ; $95 \%$ Cl: $10.928 ; 2.582$ ) more likely to have certainty in the future of VLSAs than females. Members within the age group of $₫ 30$ were 3 times (odds ratio [OR]: 3.732 ; $95 \%$ Cl: $2.316 ; 6.012$ ) were more likely to be certainty about the future of the VSLAs. Regarding occupation, those who were not employed were found 3.73 times (odds ratio [OR]: $3.732 ; 95 \% \mathrm{Cl}: 0.367 ; 1.101)$ more likely to be certain about the future of the VSLAs compared to those working. In terms of education status, those with no education were 8.85 times (odds ratio [OR]: $8.852 ; 95 \% \mathrm{Cl}: 1.033 ; 75.888$ ) more likely to be certain about the future of VSLAs compared to educated ones. When asked about the head of household status, the results show that those who are not head of household were .99 times (odds ratio [OR]: 0.998; $95 \% \mathrm{Cl}: 0.6 ; 1.658$ ) less likely to be certain about the future of VSLAs compared to household heads. Furthermore, our results show households with less than $₫ 5$ members were .84 times (odds ratio [OR]: $0.84 ; 95 \% \mathrm{Cl}: 0.518 ; 1.363$ ) less likely to be certain about the future of VSLA compared to their counterparts.

Moreover, the results of the odds ratios of the performance indicators have demonstrated that not contributing shares in good time led to .36 times (odds ratio [OR]: $0.355 ; 95 \% \mathrm{Cl}: 0.166 ; 0.759)$ more likely to lead to certainty of the VSLS. Additionally, members having meetings since the outbreak was found 1.77 times (odds ratio [OR]: $1.773 ; 95 \% \mathrm{Cl}: 1.09 ; 2.881$ ) more likely to contribute to the certainty of the VSLAs compared to not meeting. The results also revealed that an increase in the frequency of obtaining loans has .60 times (odds ratio [OR]: $0.602 ; 95 \% \mathrm{Cl}: 0.364 ; 0.998$ ) less likely to led to the certainty of VSLAs and those who agree on loan repayment not in time was found .69 times (odds ratio [OR]: $0.692 ; 95 \% \mathrm{Cl}: 0.309 ; 1.553$ ) less likely to lead to the certainty of the VSLAs in times of Covid-19.

\section{Discussion}

This study was aimed at investigating the predictors associated with the sustainability of Village Savings and Loans Associations (VSLAs) and its impact on household income levels amid of Covid-19. Our study reveals an increase in male participation in social groupings such as VSLAs despite them normally regarded as the groups for females [18]. We could attribute this development to the fact that most members of VSLAs, especially males, are considerably educated and have a positive mindset towards the groupings. However, it is not surprising to see that the majority of the respondents were unemployed despite having good education achievements. Unemployment remains a huge problem in least developed countries and Covid-19 has further crippled the economies of poor countries. Our findings are consistent with other recent studies conducted by Governments and Non-Governmental Organisational (NGO) such as, United Nations International Children's Emergency Fund (UNICEF) in developing countries like Indonesia [36, 37], Kenya [36, 37],, and developed countries like the United States of America (USA) [38], and United Kingdom (UK) [39] where they found that a decline in the levels of employment during the Covid-19 pandemic as the vast majority of continue to lose jobs. Most of the current members of VSLAs are adults who can also make well informed decisions on social-economic investments and social capital set-ups. Being a head of household automatically pushes them to join such savings groups geared to increasing their disposable income so that they can better support their families. Further, in most African cultures, children are considered as a source of wealth. Thus, it is not surprising that many households had more than five members, which is different from European, American and in Asian countries, where households have three to four members on average $[40,41]$. Studies have shown that large households is probably one of the contributing factors to unemployment, food shortages, poor women's health and other economic hardships as faced in many developing countries [42, 43].

Our study has further revealed that the outbreak of Covid-19 has negatively impacted on household income of the VSLAs members. It is evidenced that income of the vast majority of VSLAs members has drastically declined after the outbreak of Covid-19 compared to the period before Covid-19 began. Thus, the Covid-19 measures in placed by authorities in many countries such as lockdowns, curfews, and other social distances in combating the severity of the impact of the pandemic have ironically resulted in these negative consequences on people's business and economic activities [14]. Our findings agree with 
many recent studies conducted across the world on the impact of Covid-19 on different sectors of economies and household income due to disruption of supply chain, agriculture, education, sports, health, and transportations [44-46]. For example, a recent study conducted in Kenya revealed that households' income levels of those with low earnings had declined pervasively as many family members were declared redundant in their workplaces, there were reduced rate of getting gifts, and earnings from remittance rates were also reduced due to Covid-19 (Janssens et al., 2021). Likewise, a study conducted in the USA agrees with our study as they also found a pervasive decline in household income among individuals during the Covid-19 pandemic [47]. Similar results were found in a study conducted in South Africa where income earnings of most households tremendously declined leading to severe food shortages in many households [48].

Despite experiencing the negative impact of Covid-19, there is a small percentage of the members who earn above MK10,000 per month, and a slight change for those who were in this category of the lower income bands. This is clear evidence that in developing countries like Malawi, the majority of the population are still not earning a higher income either from work or business. This agrees with some studies that found that in Malawi and other developing countries, the vast majority of the populations are still earning lower income and are living under a poverty line [49,50]. In our study, we can also appreciate the impact of income inequality has played on the households coping strategies during Covid-19 pandemic. Evidence shows that those falling within the lower income levels (band) are more affected compared to those in medium and higher income levels (bands). Our findings agree with other studies that found that inequality income distribution within a society has impacted differently on households in the context of coping and recovery process during the Covid-19 pandemic period [51, 52], which gives the authorities much attention when it comes on policies implementation to cautions the impact of the Covid-19, and other future related epidemics and pandemics, disasters etc.

Regarding the sustainability of VSLAs, the results from binary logistic regression revealed that some social-demographic characteristics are significant predictors influencing the sustainability of the VSLAs in the times of Covid-19. First, being a male member had a positive impact on the certainty of the VSLAs. Drawing evidence from some physiological studies, it is argued that males are risk-takers and they tend to have positive perception on something compared to women (ceteris paribus) [53,54]. Further, this agrees to another recent study conducted in Spain on Covid-19 risk perception which found that females perceived higher dangers of Covid-19 compared to male [55]. Additionally, a study conducted in the United State of America (USA) also found that females were more afraid of Covid-19 compared to males[56]. Age groups of $\geq 31$ years old were more likely to lead to the certainty of sustainability of VSLAs, despite the fact that many factors contribute to the maturity of an individual such as age. Thus, the age group of the individuals who have moved out of adolescence and are said to be mature enough have high experience of life uncertainties[57, 58]. In regards to the fact that Covid-19 outbreak was new to be encountered, but this age-group ( $\geq 31$ years old) having, and being experienced with of life of developing countries like of Malawi, and some of Africa at general, had at one point in time experienced some of the other deadly health epidemic and pandemic like Cholera, Malaria, Ebola and etc, thus it can be argued that this could at least reduce their fear, and improved their perception [59].

In continuation, education was also found to be a significant determinant for the sustainability of VSLAs in the midst of Covid-19. Thus, the majority of VSLAs members are educated and have a positive perception of the certainty and sustainability of VSLAs compared to uneducated ones. One could argue that education increases one's awareness, information and knowledge of something gained through online and other channels of communications disseminations. Hence, this made most educated members to be well informed and have knowledge of Covid-19, which helped them to have a positive perception of it, like any other pandemic which needs to be fought with positivity. Our findings are supported and in agreement with a recent study conducted on the topic of Knowledge Attitude and Preventative Practices (KAPs) studies on Covid-19 which found a strong relationship with knowledge, attitude, and perceptions of Covid-19 among different classes of people [60-62]. Further, on socio-demographic characteristics, we found that occupation is negatively impacted on the certainty of VSLAs. Thus, members of the VSLs who were employed perceived lack of certainty and sustainability in the VLSAs. This could be explained by the fact that due to the pandemic there were a lot of job insecurity among employees as many firms were, and are at the centre of making loss due to business disruption either by lockdowns and other social distance preventative measures of Covid-19 [28, 63].

Furthermore, the study found that contribution of shares not on time by members had a positive impact on VSLAs certainty. Our study disagrees with other studies that suggest that the contributions of the shares add to the certainty, performance and sustainability of the VSLAs [16, 64]. Several reasons could be explained regarding this disagreement, some being the nature of methodological we used, the nature of Covid-19 as other studies was not conducted in times of this pandemic. However, an increase in the number of people obtaining loans from the group had a negative impact on the certainty of the VSLAs. Not surprisingly, as we also found in this study that there was a positive correlation of members not repaying loans on time. Meaning that, as the number of people obtaining loans increases, they were unable to repay loans on time which could also pose a threat as they were able to deprive the funds without replenishments. Our study also found that meetings had a positive impact on the certainty of the VSLAs. This means that physical and online meetings of the members were able to give each other social strength, hope and support achieving their agenda. Our results are supported by, and in agreement with other scholarly evidence in the field of social capital that attest that social gathering improves the mental, physical and social life of a human being [65]. Furthermore, our findings are also in agreement with other Covid-19 related studies where they found that despite being in times of Covid-19, the availability of online platforms and digital transactions, members of village savings were able to meet and transact their business making them to cope with the pandemic $[66]$.

\section{Limitations}

Despite that we have managed to achieve our aim of the study, we faced the following limitations. First, our study was a cross-sectional design, hence it was difficult to analyse causal relationships between study variables. Second, we used an online platform to collect data. As a result, the majority of the respondents had difficulties or faced hardships to find income that would enable them to buy data bundles for the internet, which is very expensive in Malawi. Also, since our study was not funded, it was challenging to convince more people to participate in the study. However, we tried to overcome this limitation by proposing a rotary gift for the group that will have the majority of the respondents. 


\section{Conclusion}

This study has found that Covid-19 has negatively impacted on the household income of the VSLAs members in Malawi. However, the impact varies based on the level of household earnings. Members of the VSLs with low-income levels are more negatively affected as compared to the medium and the higher income levels respectively. Inequality in income distribution has affected the coping and recovery strategies towards Covid-19 in Malawi. On the other hand, gender, age-group, education, shared contributions, and the continuation of meetings were significant predictors associated with the certainty and sustainability of VSLAs. In contrast, occupation and frequency of meeting were not significant predictors regarding the sustainability of VSLAs. Further, head of household, household size, and loan repayment were also not significant predictors using the binary logistic regression model. Based on the findings of our study and other scholarly works, we suggest that policymakers should continue and adopt if not those programs that would help to assist households with low income such as transfer payments which are proved to boost the income of the low earners in many poor countries in reducing the pervasive impact of the pandemic. Furthermore, we recommend that future study should be done in Malawi to analyse the impacts of Covid-19 at Macro level that would be able to try to quantify the impact.

\section{Declarations}

\section{Ethics approval and consent to participate}

Ethical clearance of this study was obtained from Yangtze University with reference Number REF/YU/2020/08. Further, the researchers observed and followed the 1964 Helsinki Declaration under conducts of research involving human beings. In accessing Mzuzu city, the clearance was obtained from Mzuzu City Council authorities in Malawi with a reference Number MCC/ dated on July 20, 2020 from the Chief Executive Officer Office. Participation in the survey was voluntary and the participants gave their informed consent to this questionnaire before completion.

\section{Consent for publication}

Not applicable.

\section{Availability of data and materials}

All data and other materials are included in the manuscript but if anything, apart from the available in the manuscript can be requested from the authors.

\section{Competing Interest}

The authors declare that they have no competing interests.

\section{Funding}

No funding was provided on this project.

\section{Authors Contributions}

All authors made a significant contribution to the work reported, whether that is in the conception, study design, execution, acquisition of data, analysis, and interpretation, or in all these areas; took part in drafting, revising, or critically reviewing the article; gave final approval of the version to be published; have agreed on the journal to which the article has been submitted; and agree to be accountable for all aspects of the work.

\section{Disclosure}

The authors declare that they have no financial or non- financial competing interests.

\section{Acknowledgement}

The authors would like to thank Yangtze University School of Economics and Management, Yangtze University International Student Office, and Mzuzu City Council Chief Executive Office for their support during the production of this paper. Further we thank all the members of the VSLAs who helped and participated in this project, Mr John Kudzala, Willie Chavula, MCA Class of 2019, Emmanuel Msofi, Linda Golosi, Violet Chande Munthali, Steven Nkhachane Kumwenda, Cuthbert Gondwe, Albert Hara, Ndamio Simkonda, Gerald Phiri, Oscar Tembo, Shakira Banda, Alice Lipenga, Lushomo Mafeni Soko. On Last note we thank Mr. Alexander Witherspoon for the final editorial work which he helped in this paper.

\section{References}


1. D NPS, Namakhwa D, George N, Munthali C, Chirambo AM. Current advancements on Covid-19 potential treatments: Learning from literature review. Int J Appl Chem Biol. 2021; January. https://www.google.com/url?

sa=t\&rct=j\&q=\&esrc=s\&source=web\&cd=\&ved=2ahUKEwjXgbLa5rTuAhXsmq0KHWqvArOQFjAFegQICxAC\&url=https\%3A\%2F\%2Fijacbs.net\%2Farticle\%2Fcurrer advancements-on-covid-19-potential-treatments-learning-from-literature-review\%2F\&usg=AOvVaw3N.

2. Mariana N. Coronavirus disease 2019 ( COVID-19). 2020. https://www.who.int/docs/default-source/coronaviruse/situation-reports/20200406-sitrep-77covid-19.pdf?sfvrsn=21d1e632_2.

3. Livingston E, Bucher K, Rekito A. Coronavirus Disease 2019 and Influenza 2019-2020. JAMA. 2020;323:1122. doi:10.1001/jama.2020.2633.

4. Yu S, Munthali GNC, Xuelian W, Kudzala JF. Effects of Government Actions on Safety and Security Perceptions of International Students during COVID-19 Pandemic in China. Asian J Med Heal. 2021;:70-82. doi:10.9734/ajmah/2021/v19i430323.

5. Addi RA, Benksim A, Amine M, Cherkaoui M. COVID-19 Outbreak and Perspective in Morocco. 2020;17:19-20.

6. Xuelian W, Munthali, George N.Chidimbah, and Xuelian W. The Future of Tobacco Industry Amidst of COVID-19 -A Case of Malawi Producing Country. Biomed J Sci Tech Res. 2020;27:21104-9. doi:10.26717/BJSTR.2020.27.004566.

7. Boyd A, Nejati M, Miyasaka M, Saniotis A, Nor S, Selvanayagam M, et al. ILO Monitor: COVID-19 and the world of work . Fifth edition Updated estimates and analysis Looking back: Labour market disruptions in the first half of 2020 Workplace closures Looking ahead: Outlook and policy challenges Part I . Looking back: Labour. J Vocat Behav. 2020;19 May:4.

8. Nnama-Okechukwu CU, Okoye UO, Obikeguna C, Onalu CE, Agha AA, Eneh J, et al. An impact study of the village savings and loan association (VSLA) in Nigeria. Etude la Popul Africaine. 2019;33:4901-12. doi:10.11564/33-2-1405.

9. Shaaban S. Reviewing Egyptian community social fund (village savings and loans association, VSLA) as an approach for community social fund. Hortic Int J. 2019;3:13-8. doi:10.15406/hij.2019.03.00105.

10. Staehle HA and M. Village Agent Training Guide. VSL Assoc. 2011; April 22:1-45.

11. The Bantwana Initiative of World Education I 44. AFRICAN YOUTH EMPOWERMENT AND DEVELOPMENT INITIATIVE (AYEDI ) VILLAGE SAVINGS AND LOAN Implementation Guide. Bantwana Initiat World Educ Inc 44. 2018; June.

12. Dean Karlan, Bram Thuysbaert, Christopher Udry BS. The Impact of Savings Groups on the Lives of the Rural Poor in Ghana, Malawi, and Uganda. CARE. 2018;501 c:1660068.

13. Karlan D, Savonitto B, Thuysbaert B, Udry C. Impact of savings groups on the lives of the poor. Proc Natl Acad Sci U S A. 2017;114:3079-84.

14. Arenas A, Cota W, Gomez-Gardenes J, Gómez S, Granell C, Matamalas JT, et al. A mathematical model for the spatiotemporal epidemic spreading of COVID19. medRxiv. 2020;:2020.03.21.20040022.

15. Ngegba MP, Project N, Meerendonk A Van De, Juergens F, Ksoll C, Lilleør HB, et al. Resilience of WE Groups in Malawi to Climate Shocks. J Dev Econ. 2016;120 May:1-10.

16. CARE Uganda. Village Saving and Loans Associations. CARE. :1-11.

17. Galvao LW, Stevens PE, Saka E, Saka T, Depete C, Valhmu LM, et al. " Mobilizing for maternal health through Village Savings \& Loan Associations in rural central Malawi ." CARE. 2012; October:4-5.

18. Beyene NL, Dinbabo MF. An Empirical Evaluation of the Link between Women Participation in Village Savings and Loans Association (VSLA) and Poverty Reduction in Ethiopia. J Rev Glob Econ. 2019;8 November:566-80. doi:10.6000/1929-7092.2019.08.49.

19. Mohamed Paul Ngegba, Tamba Lahai Kassoh \& MS. Impact of Village Saving and Loan Association ( Vsla ) on Farm Productivity in Lower Banta Chiefdo .... Impact of Village Saving and Loan Association ( Vsla ) on. Int Res J Soc Sci Humanit. 2016;VOL.1 (1) December:29-32. www.scienceandnature.org.

20. Mohammed AS, Boateng-kwakye S. Village Savings and Loans Associations and Livelihood of People in Rural Communities in the Bole District of Ghana: a Case of Village Savings and Loans Associations Supported By Jaksally Youth Group. Int J Dev Res. 2014;4 July:118-26.

21. Neuman. Methodological triangulation: an approach to understanding data. Nurse Researcher. 2006;20:40-3.

22. Heale R, Forbes D. Understanding triangulation in research. Evid Based Nurs. 2013;16:98.

23. Pierre, Habumuremyi D, Habamenshi V, Mvunabo G. Village Savings and Loan Associations and Social Economic Development of Village Savings and Loan Associations and Social Economic Development of Poor Households in Rwanda. A Case of Murundi Sector ( 2015- 2019). Int J CHUR Res Acad. 2020;Vol 2 December 2019:0-69. www.ijchura.com.

24. Munthali GNC, Wu X-L, Rizwan M, Daru GR, Shi Y. Assessment of Tobacco Control Policy Instruments, Status and Effectiveness in Africa: A Systematic Literature Review. Risk Manag Healthc Policy. 2021;Volume 14:2913-27. doi:10.2147/RMHP.S311551.

Page $8 / 14$ 
25. Munthali GNC, Xuelian W. Covid-19 Outbreak on Malawi Perspective. Electron J Gen Med. 2020;17:em210. doi:10.29333/ejgm/7871.

26. Office NS. MALAWI POPULATION AND HOUSING CENSUS REPORT-2018 2018 Malawi Population and Housing Main Report. 2019; May.

27. UN-HABITAT. Mzuzu Urban Profile. 2011. www.unhabitat.org.

28. Mogaji E. Impact of COVID-19 on transportation in Lagos, Nigeria. Transp Res Interdiscip Perspect. 2020;6 June:100154. doi:10.1016/j.trip.2020.100154.

29. Roy S. COVID-19 pandemic: Impact of lockdown, contact and non-contact transmissions on infection dynamics. medRxiv. 2020;:2020.04.04.20050328.

30. Sheet F. U. S . Social Distancing Measures for COVID-19. 2020.

31. Israel GD. Using Published Tables Using Formulas To Calculate A Sample Size Using A Census For Small Populations. Univ Florida IFAS Ext. 2003.

https://www.google.com.hk/url?

$s a=t \& r c t=j \& q=\& e s r c=s \&$ source=web\&cd=\&cad=rja\&uact=8\&ved=2ahUKEwjX6qeV46PzAhUjL30KHaTcCRQQFnoECAMQAQ\&url=https\%3A\%2F\%2Fwww.tarleton

32. Iqbal MA, Rizwan M, Abbas A, Makhdum MSA, Kousar R, Nazam M, et al. A Quest for Livelihood Sustainability? Patterns, Motives and Determinants of Non-Farm Income Diversification among Agricultural Households in Punjab, Pakistan. Sustainability. 2021;13:9084. doi:10.3390/su13169084.

33. Rahman A, Islam MA, Yeasmin S. Influencing Factors of Fertility in Developing Countries: Evidence from 16 DHS Data. J Int Womens Stud. 2020;21:41626. https://www.google.com.hk/url?sa=t\&rct=j\&q=\&esrc=s\&source=web\&cd=\&cad=rja\&uact=8\&ved=2ahUKEwjeq-

CSk9jyAhWXCjQIHbipALMQFnoECAMQAQ\&url=https\%3A\%2F\%2Fvc.bridgew.edu\%2Fjiws\%2Fvol21\%2Fiss6\%2F27\%2F\&usg=AOvVaw33DEeFUgNOILswpCls8v

34. Shahzad MA, Qing P, Rizwan M, Razzaq A, Faisal M. COVID-19 Pandemic, Determinants of Food Insecurity, and Household Mitigation Measures: A Case Study of Punjab, Pakistan. Healthcare. 2021;9:621. doi:10.3390/healthcare9060621.

35. Oldfield F. An introduction to models and modelling. Environ Chang. 2012; October:19-33.

36. UNICEF, UNDP, Prospera, SMERU. Analysis of the Social and Economic Impacts of COVID-19 on Households and Strategic Policy Recommendations for Indonesia. Jakarta. 2021.

37. Janssens W, Pradhan M, de Groot R, Sidze E, Donfouet HPP, Abajobir A. The short-term economic effects of COVID-19 on low-income households in rural Kenya: An analysis using weekly financial household data. World Dev. 2021;138:105280. doi:10.1016/j.worlddev.2020.105280.

38. Center on Budget and Policy Priorities. Tracking the COVID-19 Recession's Effects on Food, Housing, and Employment Hardships Emerging Data Show High Rates of Hardship. 2020;:1-21. https://www.cbpp.org/blog/food-need-very-high-compared-to-pre-pandemic-levels-making-relief-imperative.

39. Treasury H. Impact_of_COVID-19_on_working_household_incomes. 2020; May. www.gov.uk/official-documents.

40. The Lancet. Child wellbeing in Africa: the true wealth of nations. Lancet. 2010;376:1960. doi:10.1016/S0140-6736(10)62245-3.

41. Ware H. Economic Value of Children in Asia and Africa: Comparative Perspectives. Determ Fertil Dev Ctries A Summ Knowl. 1978 ;:6.

42. Espenshade TJ, Kamenske G, Turchi BA. Family size and economic welfare. Fam Plann Perspect. 1983;15:289-94. doi:10.2307/2135299.

43. Peichl A, Schneider H, Peichl A, Pestel N. Does Size Matter? The Impact of Changes in Household Structure on Income Distribution in Germany. 2010.

44. Bennihi AS. Assessment Of The Impact Of Covid-19 Pandemic On The Algerian Economy: The Importance Of The Informal Economy ON THE ALGERIAN ECONOMY: 2020; July.

45. Gupta A, Goplani MM. Purakala ( UGC Care Journal) IMPACT OF COVID-19 ON EDUCATIONAL IMPACT OF COVID-19 ON EDUCATIONAL INSTITUTIONS IN INDIA. 2020; May.

46. Munthali GNCC, Xuelian W. Covid-19 Outbreak on Malawi Perspective. Electron J Gen Med. 2020;17:em210. doi:10.29333/ejgm/7871.

47. Chen CYC, Byrne E, Vélez T. Impact of the 2020 pandemic of COVID-19 on Families with School-aged Children in the United States: Roles of Income Level and Race. J Fam Issues. 2021;:1-22.

48. Arndt C, Davies R, Gabriel S, Harris L, Makrelov K, Robinson S, et al. Covid-19 lockdowns, income distribution, and food security: An analysis for South Africa. Glob Food Sec. 2020;26:100410. doi:10.1016/j.gfs.2020.100410.

49. GFSI. Malawi Food Security. GFSI. 2020. https://foodsecurityindex.eiu.com/Country/Details\#Malawi. Accessed 20 Sep 2020.

50. Muhome-Matita M, Chirwa EW. Agricultural Growth and Poverty in Rural Malawi. 2011; July.

51. Darvas Z. The Unequal Inequality Impact of the Covid-19 Pandemic. Work Pap 06/2021, Bruegel. 2021;:1-25.

52. Nikolay Angelov DW. Income inequality during the Covid-19 pandemic | VOX, CEPR Policy Portal. 2021. https://voxeu.org/article/income-inequality-duringcovid-19-pandemic. Accessed 31 Aug 2021.

Page 9/14 
53. Charness G, Gneezy U. Strong Evidence for Gender Differences in Risk Taking. J Econ Behav Organ. 2012;83:50-8. doi:10.1016/j.jebo.2011.06.007.

54. Pawlowski B, Atwal R, Dunbar RIM. Sex Differences in Everyday Risk-Taking Behavior in Humans. Evol Psychol. 2008;6:147470490800600. doi:10.1177/147470490800600104.

55. Rodrigues GS, Martins CR, de Barros I. Sustainability assessment of ecological intensification practices in coconut production. Agric Syst. 2018;165:7184. doi:https://doi.org/10.1016/j.agsy.2018.06.001.

56. Alsharawy A, Spoon R, Smith A, Ball S. Gender Differences in Fear and Risk Perception During the COVID-19 Pandemic. Front Psychol. $2021 ; 12$. doi:10.3389/fpsyg.2021.689467.

57. Morgan M. Variation in maturity-at-age and size in three populations of American plaice. ICES J Mar Sci. 1999;56:673-88. doi:10.1006/jmsc.1999.0487.

58. Sawyer SM, Azzopardi PS, Wickremarathne D, Patton GC. The age of adolescence. Lancet Child Adolesc Heal. 2018;2:223-8. doi:10.1016/S2352-

4642(18)30022-1.

59. DOA. Annual Report 2016-17. Clim Chang 2013 - Phys Sci Basis. 2017;:194.

60. Wu X-L, Munthali GNC. Knowledge, Attitudes, and Preventative Practices (KAPs) Towards COVID-19 Among International Students in China. Infect Drug Resist. 2021;Volume 14:507-18. doi:10.2147/IDR.S291199.

61. Ejeh FE, Saidu AS, Owoicho S, Maurice NA, Jauro S, Madukaji L, et al. Knowledge, attitude, and practice among healthcare workers towards COVID-19 outbreak in Nigeria. Heliyon. 2020;6:e05557. doi:10.1016/j.heliyon.2020.e05557.

62. Tadesse DB. Knowledge, Attitude, Practice and Psychological response toward COVID-19 among Nurses during the COVID-19 outbreak in Northern Ethiopia , 2020. 2020;:1-14. doi:10.21203/rs.3.rs-26236/v1.

63. Munthali GNC, Xuelian W. COVID-19 Lockdown Measures on Least Developing Economies in Africa-a case of Malawi Economy. Tech Soc Sci J. 2020;7 Vol 7:295-301. doi:10.47577/tssj.v7i1.394.

64. Alesane A, Yussif K, Tetteh Anang B. Determinants of Village Savings and Loans Association membership and savings amounts in Awutu Senya West District of Ghana. Cogent Econ Financ. 2020;7. doi:10.1080/23322039.2019.1707004.

65. Cassar A, Wydick B. Does Social Capital Matter? Evidence from a Five- Country Group Lending Experiment Does Social Capital Matter? Evidence from a Five-Country Group Lending Experiment. 2010;62:715-39.

66. Jayaram; EN de HHSC. EVIDENCE REVIEW OF WOMEN'S GROUPS AND COVID-19: IMPACTS , CHALLENGES , AND POLICY IMPLICATIONS FOR SAVINGS GROUPS IN AFRICA. CARE. 2021.

\section{Tables}

Table 1: Variables Definitions and coding 


\begin{tabular}{|c|c|c|c|}
\hline \multirow[b]{2}{*}{ Variables } & \multirow[b]{2}{*}{ Category } & \multicolumn{2}{|c|}{ Categorical Variables Coding } \\
\hline & & Frequency & Parameter coding \\
\hline \multirow[t]{2}{*}{ Gender } & Male & 259 & 0 \\
\hline & Female & 142 & 1 \\
\hline \multirow[t]{2}{*}{ Age-group } & $<30$ & 157 & 0 \\
\hline & $\geq 31$ years old & 244 & 1 \\
\hline \multirow[t]{2}{*}{ Occupation } & Otherwise & 288 & 0 \\
\hline & Employed i.e Civil servant or NGOs & 113 & 1 \\
\hline \multirow[t]{2}{*}{ Education Level } & otherwise & 14 & 0 \\
\hline & attended education & 387 & 1 \\
\hline \multirow[t]{2}{*}{ Are you head of the house } & No & 122 & 0 \\
\hline & Yes & 279 & 1 \\
\hline \multirow[t]{2}{*}{ Number of people in the house } & $\otimes 5$ members & 139 & 0 \\
\hline & $6 \geq$ & 262 & 1 \\
\hline \multirow[t]{2}{*}{ Loan Repayment not on time } & No & 77 & 0 \\
\hline & Yes & 324 & 1 \\
\hline \multirow[t]{2}{*}{ Loan obtainment Frequency } & Decreased & 274 & 1 \\
\hline & Increased & 127 & 0 \\
\hline \multirow[t]{2}{*}{ Shares contribution not time } & No & 89 & 0 \\
\hline & Yes & 312 & 1 \\
\hline \multirow[t]{2}{*}{ Meeting's continuations } & No & 160 & 0 \\
\hline & Yes & 241 & 1 \\
\hline
\end{tabular}

Source: Authors 2021 Coded Using SPSS Software

Table 2: Social demographic characteristics and Future of VSLAs $(\mathrm{N}=402)$

\begin{tabular}{|c|c|c|c|c|c|c|c|}
\hline \multicolumn{8}{|c|}{ Future of VSLAs Is } \\
\hline Variables & Category & Certain & Not Certain & $\mathbf{n}$ & $\%$ & $\chi 2$ Test & P-value \\
\hline \multirow[t]{2}{*}{ Gender } & Male & 131 & 128 & 259 & 64.4279 & \multirow[t]{2}{*}{4.462} & \multirow[t]{2}{*}{$.035 * \star$} \\
\hline & Female & 88 & 55 & 142 & 35.3234 & & \\
\hline \multirow[t]{2}{*}{ Age group } & $<30$ & 56 & 101 & 157 & 39.0547 & \multirow[t]{2}{*}{36.749} & \multirow[t]{2}{*}{$.000 * \star \star$} \\
\hline & $\geq 31$ years old & 163 & 82 & 244 & 60.6965 & & \\
\hline \multirow[t]{2}{*}{ Occupation } & Otherwise & 152 & 137 & 288 & 71.6418 & \multirow[t]{2}{*}{1.469} & \multirow[t]{2}{*}{0.225} \\
\hline & Employed & 67 & 46 & 113 & 28.1095 & & \\
\hline \multirow[t]{2}{*}{ Education Level } & otherwise & 1 & 13 & 14 & 3.48259 & \multirow[t]{2}{*}{13.105} & \multirow[t]{2}{*}{$.000 * \star \star$} \\
\hline & attended education & 218 & 170 & 387 & 96.2687 & & \\
\hline \multirow[t]{2}{*}{ Head of the house } & No & 118 & 65 & 122 & 30.3483 & \multirow[t]{2}{*}{4.249} & \multirow[t]{2}{*}{$.039 * *$} \\
\hline & Yes & 162 & 57 & 279 & 69.403 & & \\
\hline \multirow[t]{2}{*}{ Household Total (Pple) } & $\nabla 5$ members & 76 & 63 & 139 & 34.5771 & \multirow[t]{2}{*}{0.003} & \multirow[t]{2}{*}{0.954} \\
\hline & $6 \geq$ members & 143 & 120 & 262 & 65.1741 & & \\
\hline
\end{tabular}

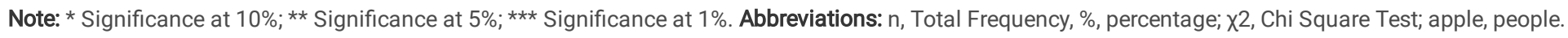

Table 3: Impact of Covid-19 on Income earnings (Income changes due to Covid-19) among VSLAs Members 


\begin{tabular}{|c|c|c|c|c|c|c|c|c|}
\hline & & \multicolumn{7}{|c|}{ Income Bands } \\
\hline & \multirow[t]{2}{*}{ Category } & Q & $M K 5,000 \geq M K 10,000$ & $>\mathrm{MK} 10,000$ & Mean & $S D$ & F-Value & P-Value \\
\hline & & MK5,000 & & & & & & \\
\hline \multirow[t]{2}{*}{ Period } & Before Covid-19 & 63 & 201 & 138 & 2.19 & 0.7 & 103.705 & $.000 * *$ \\
\hline & During Covid-19 & 137 & 145 & 120 & 1.96 & 0.8 & 101.780 & $.000 * \star$ \\
\hline \multirow[t]{2}{*}{ Changes } & Frequency (n) & 74 & -56 & -18 & & & & \\
\hline & Percentage (\%) & 54.01 & -38.62 & -15 & & & & \\
\hline
\end{tabular}

Source: Authors 2021;

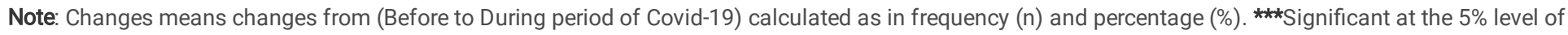
significance. (One Way ANOVA). 1 USD= MK811.37.

Table 4: Predictors of the certainty of the Future and sustainability of VSLAs during Covid-19 using by Binary Logistic Regression Model

\begin{tabular}{|c|c|c|c|}
\hline Variables & $\beta$ & OR & $95 \%$ C. I \\
\hline Gender of the respondent (1) & $0.437(0.094) *$ & 1.548 & {$[0.928 ; 2.582]$} \\
\hline Age group (1) & $1.317(0.000) * \star \star$ & 3.732 & {$[2.316 ; 6.012]$} \\
\hline Occupation (1) & $-0.453(0.106)$ * & 0.636 & {$[0.367 ; 1.101]$} \\
\hline Education Level (1) & $2.181(0.047) * *$ & 8.852 & {$[1.033 ; 75.888]$} \\
\hline Are you head of the house (1) & $-0.002(0.994)$ & 0.998 & {$[0.6 ; 1.658]$} \\
\hline Number of people in the house (1) & $-0.174(0.481)$ & 0.84 & {$[0.518 ; 1.363]$} \\
\hline Shares contribution not on Time & $1.035(0.008) * \star \star$ & 0.355 & {$[0.166 ; 0.759]$} \\
\hline Frequency of loans obtaining increasing & $-0.507(0.049) * \star *$ & 0.602 & [0.364;0.998] \\
\hline Loan Repayment not on time & $-0.368(0.372)$ & 0.692 & {$[0.309 ; 1.553]$} \\
\hline Meetings & $0.572(0.021) * * *$ & 1.773 & {$[1.09 ; 2.881]$} \\
\hline Constant & $-1.506(0.211)$ & 0.222 & \\
\hline Model Predicted Success & $68.10 \%$ & & \\
\hline Log-likelihood ratio & 465.102 & & \\
\hline Hosmer and Lemeshow Test & \multicolumn{3}{|c|}{$(\mathrm{df}=8)$ significance test result $8.469(P$-value= 0.389$)$} \\
\hline Omnibus Tests of Model Coefficients & \multicolumn{3}{|c|}{$(\mathrm{df}=10)$ significance test result $87.387(P-$ value $=0.000 * \star \star)$} \\
\hline Cox and Snell R2 & \multicolumn{3}{|l|}{$0.196 * \star \star$} \\
\hline Negelkerke R2 & \multicolumn{3}{|l|}{$0.262^{\star \star \star}$} \\
\hline Sample Number (n) & \multicolumn{3}{|l|}{420} \\
\hline
\end{tabular}

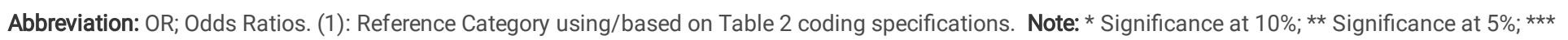
Significance at $1 \%$.

\section{Figures}




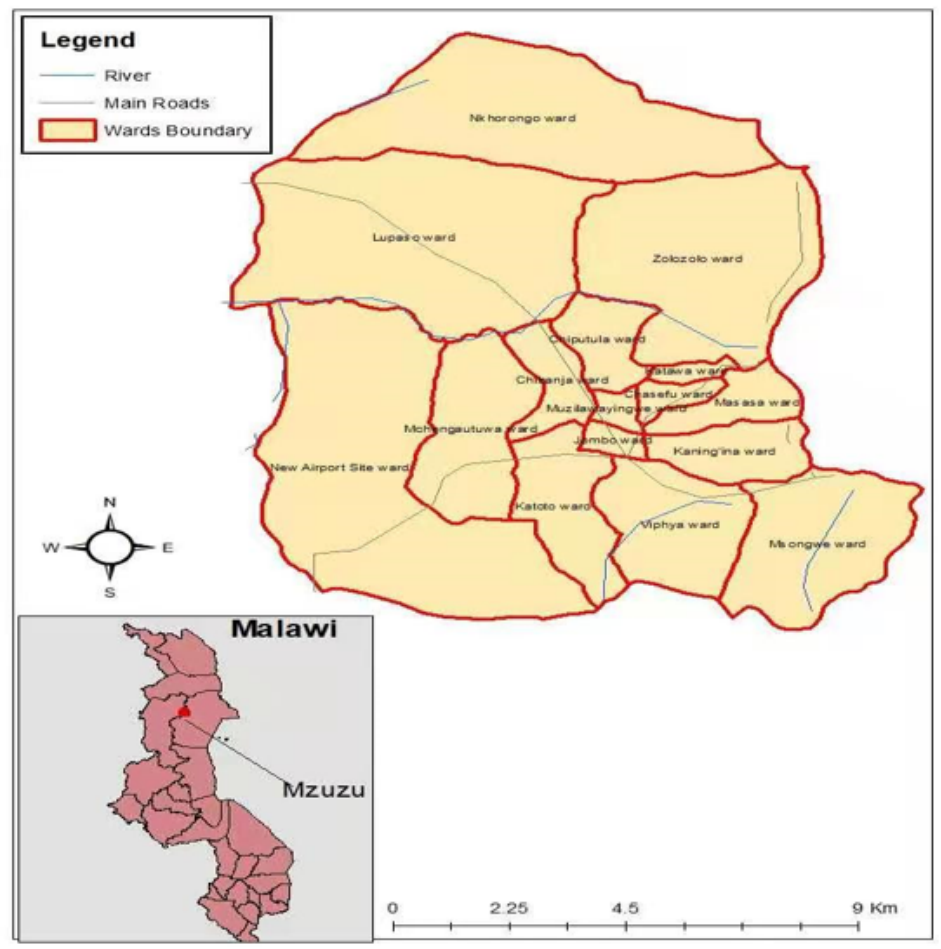

Figure 1

\section{Study Area of Mzuzu}

Source: Authors 2021

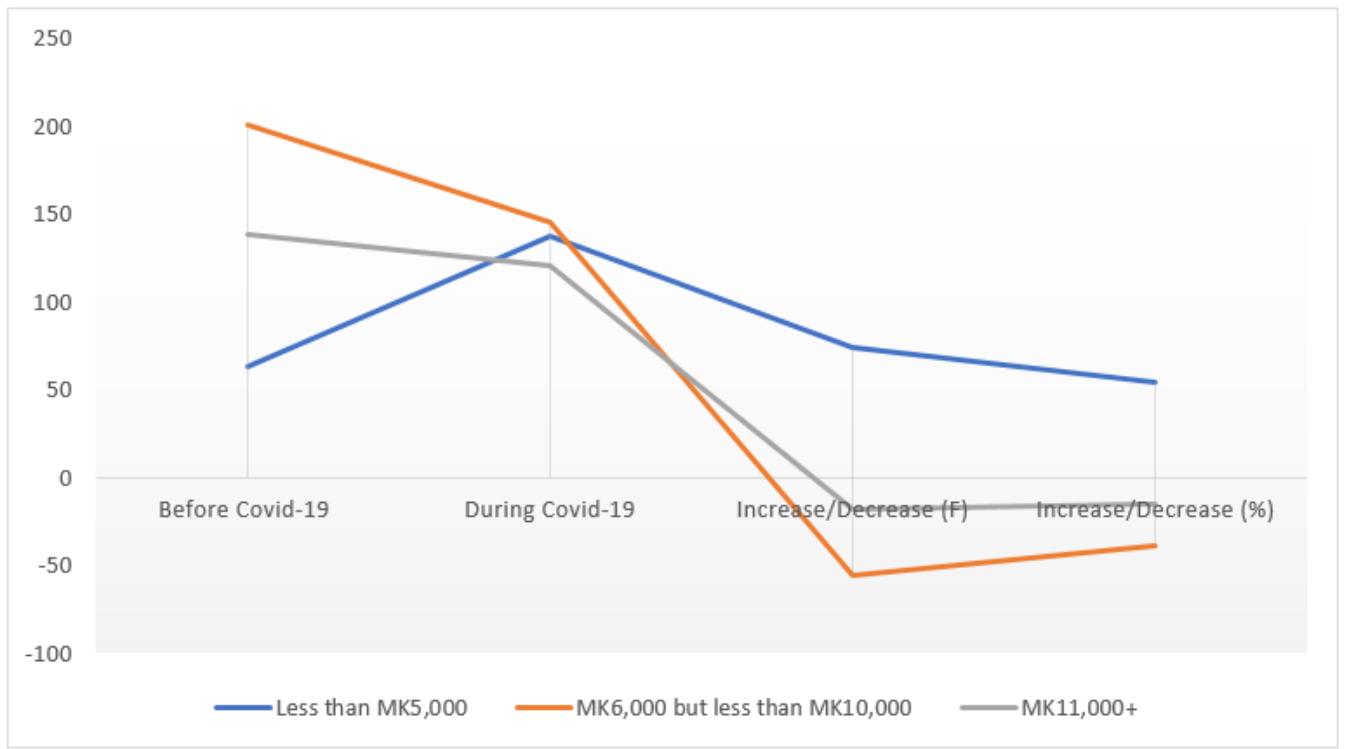

\section{Figure 2}

Impacts of Covid-19 on Households Income of VSLAs Members

Source: Authors 2021 


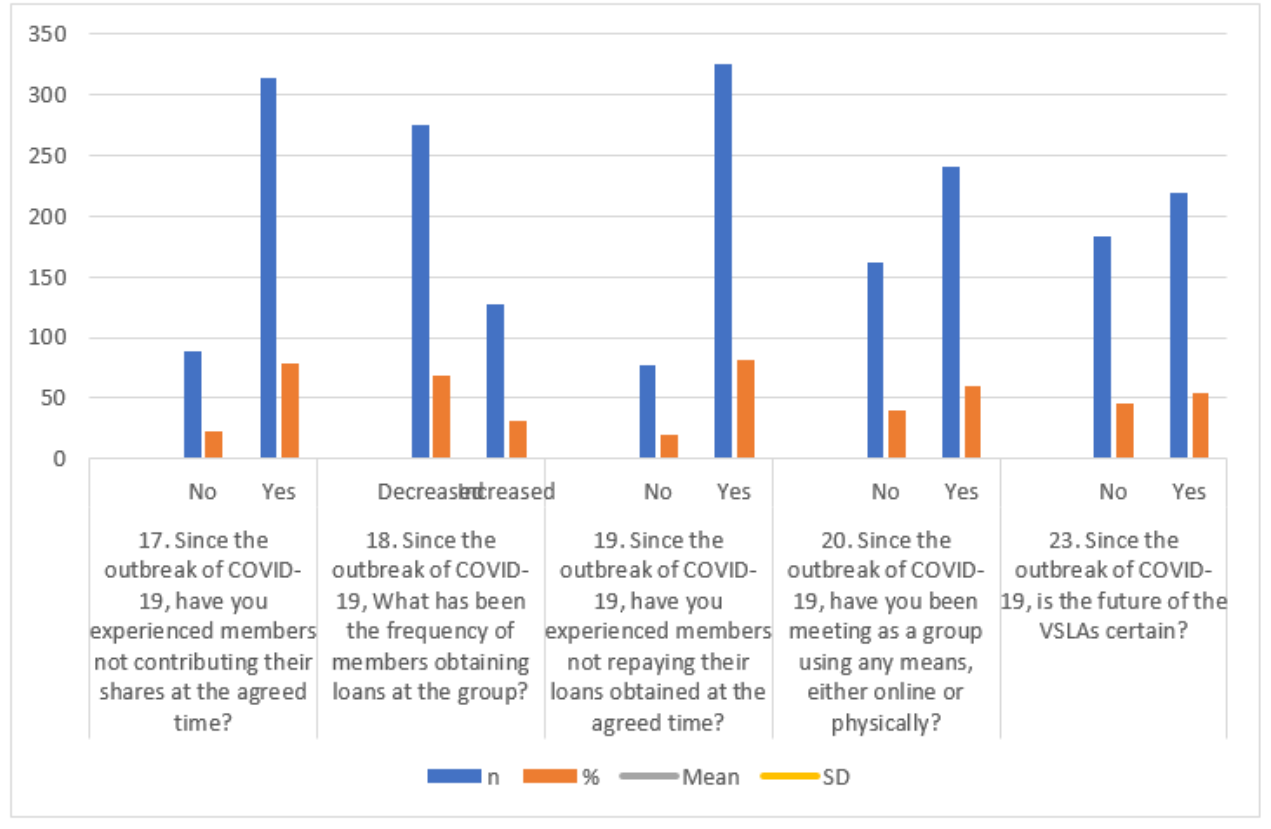

Figure 3

Figure 3: Impact of Covid-19 on VSLAs set ups

Source: Authors 2021 